\title{
The Russian Arctic by 2050: Developing Integrated Scenarios
}

\author{
Andrey N. Petrov, ${ }^{1}$ Marya S. Rozanova Smith, ${ }^{2,3}$ Andrey K. Krivorotov, ${ }^{4}$ Elena M. Klyuchnikova, ${ }^{5}$ \\ Valeriy L. Mikheev, ${ }^{3}$ Alexander N. Pelyasov ${ }^{6,7}$ and Nadezhda Yu. Zamyatina ${ }^{7}$
}

(Received 3 July 2020; accepted in revised form 1 April 2021)

\begin{abstract}
Scenarios of future development pathways in the Arctic created by groups of experts and stakeholders are an effective way to identify and illustrate possible alternatives and options for this region based on anticipated environmental and socioeconomic changes. Although scenarios that assess development trajectories for the Arctic are becoming increasingly popular, there is a relative lack of regional perspective in foresight exercises devoted to the Russian Arctic. This article presents and discusses development scenarios for the Russian Arctic until 2050 that were built by a diverse group of academics, local officials, Indigenous leaders, and business representatives at a scenario workshop in Naryan-Mar, Russia. The scenarios focus on Russia's Arctic zone and incorporate future visioning of economic development, international cooperation with the West and China, shipping, human and social capital, and Indigenous Peoples' livelihoods in the context of climate change. We apply a novel circular-axial technique to synthesize and combine the 12 initially created thematic scenarios into four final cross-cutting integrated scenarios that describe alternative futures for the Russian Arctic by 2050: Harmonious Arctic, Self-Reliant Arctic, Resource-Dependent Arctic, and Forgotten Arctic.
\end{abstract}

Key words: Arctic; scenarios; Russia; Indigenous Peoples; economic development; Arctic policy

RÉSUMÉ. Les scénarios de trajectoires de développement futur dans l'Arctique créés par des groupes d'experts et de parties prenantes constituent une manière efficace de déterminer et d'illustrer des solutions de rechange et des options possibles pour cette région, en fonction des changements environnementaux et socioéconomiques attendus. Même si les scénarios évaluant les trajectoires de développement dans l'Arctique gagnent en popularité, les exercices de prévision sont caractérisés par le manque relatif de perspective régionale axée sur l'Arctique russe. Cet article présente et aborde des scénarios de développement pour l'Arctique russe. Ces scénarios s'étendent jusqu'en 2050 et sont le fruit du travail de divers groupes d'universitaires, d'autorités locales, de chefs autochtones et de représentants du monde des affaires ayant participé à un atelier de scénarios qui s'est déroulé à Naryan-Mar, en Russie. Les scénarios se concentrent sur la zone arctique russe et intègrent la vision future du développement économique, de la coopération internationale avec l'Ouest et la Chine, du transport, du capital humain et social et de la subsistance des peuples autochtones dans le contexte du changement climatique. Nous appliquons une technique circulaire-axiale nouvelle pour synthétiser et combiner les 12 scénarios thématiques initialement créés afin d'aboutir à quatre scénarios intersectoriels intégrés décrivant les solutions de rechange futures pour l'Arctique russe d'ici 2050, soit un Arctique harmonieux, un Arctique autonome, un Arctique dépendant des ressources, et un Arctique oublié.

Mots clés : Arctique; scénarios; Russie; peuples autochtones; développement économique; politique des questions arctiques

Traduit pour la revue Arctic par Nicole Giguère.

АННОТАЦИЯ. Создаваемые экспертами и участниками процесса сценарии регионального развития являются эффективным способом выявления возможных альтернатив и вариантов развития регионов с учетом ожидаемых климатических и социально-экономических изменений. Несмотря на то, что сценарии, описывающие траектории развития Арктики в целом, становятся все более популярными, имеет место относительная нехватка региональных сценариев, посвященных российской Арктике. В данной статье представлены сценарии регионального развития

\footnotetext{
${ }^{1}$ Corresponding author: ARCTICenter, University of Northern Iowa, 1227 West 27th Street, Cedar Falls, Iowa 50614, USA; andrey.petrov@uni.edu

${ }^{2}$ Department of Geography, The George Washington University, Samson Hall, 2036 H Street NW, Washington, D.C. 20052, USA

${ }^{3}$ Rector's Office, Russian State Hydrometeorological University, 79 Voronezhskaya Street, St. Petersburg 192007, Russia

${ }^{4}$ Innovation Management Department, Odintsovo Branch, Moscow State Institute of International Relations (MGIMO University) and Shtokman Development AG, 3 Novo-Sportivnaya Street, Odintsovo, Moscow District 143007, Russia

${ }^{5}$ Institute of North Industrial Ecology Problems, Kola Science Centre of the Russian Academy of Sciences, 14, Fersman Street, Apatity, Murmansk Region, Russia

${ }^{6}$ Institute of Regional Consulting, 17B Butlerova Street, Moscow 117342, Russia

${ }^{7}$ Faculty of Geography, Lomonosov Moscow State University, ul. Leninskiye Gory, 1, Moscow 119991, Russia

(C) The Arctic Institute of North America
} 
российской Арктики до 2050 года, которые были разработаны на форсайт-семинаре в Нарьян-Маре (Россия). В состав участников форсайт-семинара вошли ученые, представители органов государственной власти, бизнеса и коренных народов Севера. Представленные сценарии сосредоточены на Арктической зоне России и включают в себя видение будущего экономического развития, судоходства, человеческого и социального капитала, международного сотрудничества со странами Запада и с Китаем, а также образа жизни коренных народов в контексте изменения климата. С целью интеграции двенадцати первоначально созданных тематических сценариев была применена новая круговая аксиальная методика, позволившая на их основе синтезировать следующие четыре финальных сценария, описывающие альтернативы будущего развития российской Арктики до 2050 года: «Гармоничная Арктика», «Самостоятельная Арктика», «Ресурсная Арктика» и «Ненужная Арктика».

Ключевые слова: Арктика; сценарии; Россия; коренные народы; экономическое развитие; арктическая политика.

\section{INTRODUCTION}

Scenario building is one of the most important instruments of a long-term strategic foresight for regional development (for the purpose of the paper, the term 'region' refers to a subnational territorial unit). It allows the integration of diverse systematic knowledge and various forecasts in order to define driving forces and create alternatives for the possible and plausible futures of a region (Brigham, 2008; Lovecraft and Eicken, 2011; Karlsdottir et al., 2017; Flynn et al., 2018; Falardeau et al., 2019; Nilsson et al., 2019). Unlike other foresight- and goal-oriented approaches, such as strategy planning, forecasting, roadmapping, or risk assessment, which are aimed at creating a singular foresight vision in the process of "predicting the future by accumulating and interpreting patterns from the past to extrapolate models of the future" (Gidley, 2017:2), scenario building is based on the theoretical assumption that a single, predictable future has no grounds in reality. It is particularly relevant given multiple uncertainties of environmental and socioeconomic trends in the Arctic. First used in the middle of the 20th century, the scenario method originated from war game analysis and is now widely used in business planning and policymaking processes (Swart et al., 2004; AMSA/PAME, 2008; Martelli, 2014; Popiel, 2014; Gong at al., 2017; Haigh, 2019; USAF, 2019; U.S. Committee on the Marine Transportation System, 2019).

A scenario is a hypothetical series of events occurring largely due to cause-and-effect relationships and decisions taken at turning points, such as acts of political leadership or technological breakthroughs (Kahn and Weiner, 1967). In addition, bifurcations serve as an integral element of indeterminism in the context of unstable, complex, and dynamic socio-economic systems (Nicolis and Prigogine, 1989; Prigogine and Stengers, 1997). A scenario is not a forecast or a prediction, but a logical description of multiple options for future development (broadly defined to include social, economic, and environmental change) based on an understanding of the nature and dynamics of processes and phenomena, their trends as well as hypothetically (im) possible and (im)permissible uncertainties.

The scenario method's advantage over other approaches to long-term planning is an ability to identify plausible future scenarios of dynamic systems under conditions of uncertainty. Elements of scenario methodologies are often used, for example, to identify climate change trajectories and adaptation strategies and regional socioeconomic forecasting (Berkhout et al., 2002; Kok et al., 2007; Lovecraft and Eicken, 2011; Kahane, 2012; Miles et al., 2016). Moreover, such a practice-oriented approach often allows global scenarios of adaptation to climate change (O’Neill et al., 2014) to serve as a guide for regional planning strategies.

In the Arctic, scenario approaches have gained popularity in recent years (Brigham, 2008; Lovecraft and Eicken, 2011; Arbo et al., 2013; Wesche and Armitage, 2014; Haavisto et al., 2016; Rasmussen and Jungsberg, 2016; Gong et al., 2017; Jacobsen et al., 2017; Lovecraft et al., 2017a, b; Nilsson et al., 2017a, b; Wormbs, 2018). The scenario approach is highly relevant for the Russian Arctic, also in operational terms regarding the national Arctic Strategy. Designed for the first time in 2008-14, the Strategy has since evolved under increasing uncertainties, which were caused, for example, by international sanctions, Russia's pivot to the East, and dramatic fluctuations in prices for raw materials, including notably for oil and gas (Klimenko, 2014; Konyshev et al., 2017; Gritsenko and Efimova, 2020). The 2014 Russian Federal Law on strategic planning stipulates that strategies of territorial socioeconomic development are to be adopted both at the federal and regional levels and shall reflect the national long-term forecast, which, in turn, will outline and quantify various development paths reflecting the evolution of internal and external conditions (Federal Law, 2014).

Russian experts have proposed medium and long-term development scenarios for international relations in the Arctic (Razuvaev, 2016) for Arctic regional industries (Klyuchnikova et al., 2017) and critical infrastructure systems (Tsukerman and Ivanov, 2013). A joint RussianNorwegian team has charted comprehensive scenarios for bilateral cooperation in developing the Barents Sea petroleum resources, including notably its effects on political relations, regional business, resource management, and the environment (Bourmistrov et al., 2015).

However, construction of integrated, interdisciplinary scenarios for the Russian Arctic as a whole with the participation of both Russian and international experts and stakeholders has not yet been carried out. To fill this gap and contribute to the development and implementation of deliberative democracy principles and practices 
(see Lovecraft et al., 2017b:221), the workshop "Arctic Futures-Scenarios for Russia" was organized in the polar city of Naryan-Mar (Nenets Autonomous Okrug, Russia) in November 2018. (This workshop was a result of a joint effort between the ARCTICenter, University of Northern Iowa, and the Russian State Hydrometeorological University.)

The goal of the workshop was to build scenarios for the Russian Arctic by 2050 (approximately 30 years or a time span of one generation [Troll, 1970]). The main questions to answer were (1) What are the key driving forces that will define the future of the Arctic zone by 2050? and (2) What are the likely scenarios of Arctic development with respect to (a) Arctic coast development in the context of Arctic shipping, environmental change, and international cooperation; (b) economic development; and (c) social change, human capital, and Indigenous Peoples' livelihoods? Answering these questions necessitates multiple scenarios for each of the development domains, which could be subsequently converged to elucidate integrated scenarios. For the purposes of this workshop, the Russian Arctic was defined according to the official designation of the Arctic Zone of the Russian Federation (AZRF). The AZRF, as defined and amended in several presidential decrees since 2014 (President of Russian Federation, 2014), is a relatively narrow set of territories crossed by or north of the Arctic Circle. It covers nearly five million $\mathrm{km}^{2}$ or almost $30 \%$ of Russia's territory and is home to 2.4 million residents (Blakkisrud, 2019). However, the scenarios would likely be applicable to the adjacent northern territories of Russia.

\section{METHODOLOGY, FORMAT, AND TECHNIQUES}

Scenario building is considered to be an exceptionally suitable full-scale foresight method to write the narratives of alternative futures (UNDP, 2015, 2018; Teh et al., 2017), which has proven to work well for the Arctic (Rounsevell and Metzger, 2010; Hansen and Larsen, 2014; Wesche and Armitage, 2014; Karlsdóttir et al., 2017; Klyuchnikova et al., 2017). In particular, scenario building encourages incorporating diverse opinions of stakeholders, decisionmakers, constituents, and subject-matter experts. It implements the principle of inclusiveness to make sure that "whoever has a stake and a role in the realization of a particular future, is also entitled and required to have a say in how that future should look like" (UNDP, 2018:6). Scenario building also envisages measures for the realization of various regional development paths; thus, the outcomes of scenario-building techniques are actionoriented and useful to decision-makers and stakeholders (Klyuchnikova et al., 2017).

There are two basic approaches to the development of regional scenarios - top-down and bottom-up. The first approach imposes a preconditioned framework for scenario generation, for instance, global development or climate change variants as a starting point or context (Biggs et al., 2007; Nilsson et al., 2017a). The bottom-up approach implies the absence of preassigned frames and involves both active and open involvement of experts and all parties concerned to make scenarios based on their knowledge (Rotmans et al., 2000; Kok et al., 2006; Beach and Clark, 2015). However, the top-down vs. bottom-up approaches represent the ends of a spectrum rather than clear-cut categories (Lovecraft et al., 2017b).

Unlike previously used practices of frameworkscenario building in the northern regions, such as shared socioeconomic pathways (SSP) that employ a preset array of plausible alternative trends (O'Neill et al., 2014), our task was to stimulate all participants to develop their own future visions and to create fundamentally new scenarios. We considered this option more appealing to generate diverse and inclusive scenarios based on high levels of uncertainty. In addition, we considered other benefits of this approach, including its ability to stimulate a dialogue among participants with varying positioning and views and thus elevate the scenarios' credibility, relevance, and legitimacy among stakeholders through procedural equity (Chaudhury et al., 2012; Lovecraft et al., 2017b).

Based on the bottom-up method, the workshop in Naryan-Mar was organized to maximize the contribution made by each participant and ensure freedom of speech and expression, open dialogue, and independence of thoughts, approaches, and opinions. This method was especially important in connection with the diverse composition of the workshop participants and the roles that many of them play in the Arctic region.

An inclusive approach was used when defining a pool of participants to include natural and social scientists and policy representatives from different branches of government, policy experts and stake-, rights-, and knowledge-holders, including Indigenous Peoples, from diverse Arctic geographic areas. As a result, the diverse group of participants included 20 academic and policy experts from various Arctic regions of Russia (Nenets Autonomous District, Arkhangelsk, Murmansk, and the Republic of Sakha (Yakutia)) and other Arctic countries (USA, Sweden, and Norway), six government and business decision-makers (federal and Nenets District's governments, executive and legislative branches, oil sector, and northern media), and four Indigenous leaders (representatives of the Russian Association of Indigenous Peoples of the North, Siberia, and the Far East (RAIPON); the Nenets People Association 'Yasavey'; and the Yukaghir People Association of the Republic of Sakha (Yakutia)). At the same time, the limitations on participation in scenario exercises and demographic, gender, ethnic, social, economic, and political imbalances among participants constitute typical shortcomings of such workshops and may make the outcomes less representative.

The workshop was scheduled as a two full-day event with side discussions on the third day (see Fig. 1). In the first stage, the experts, both natural and social scientists, presented a series of reports on the current conditions 


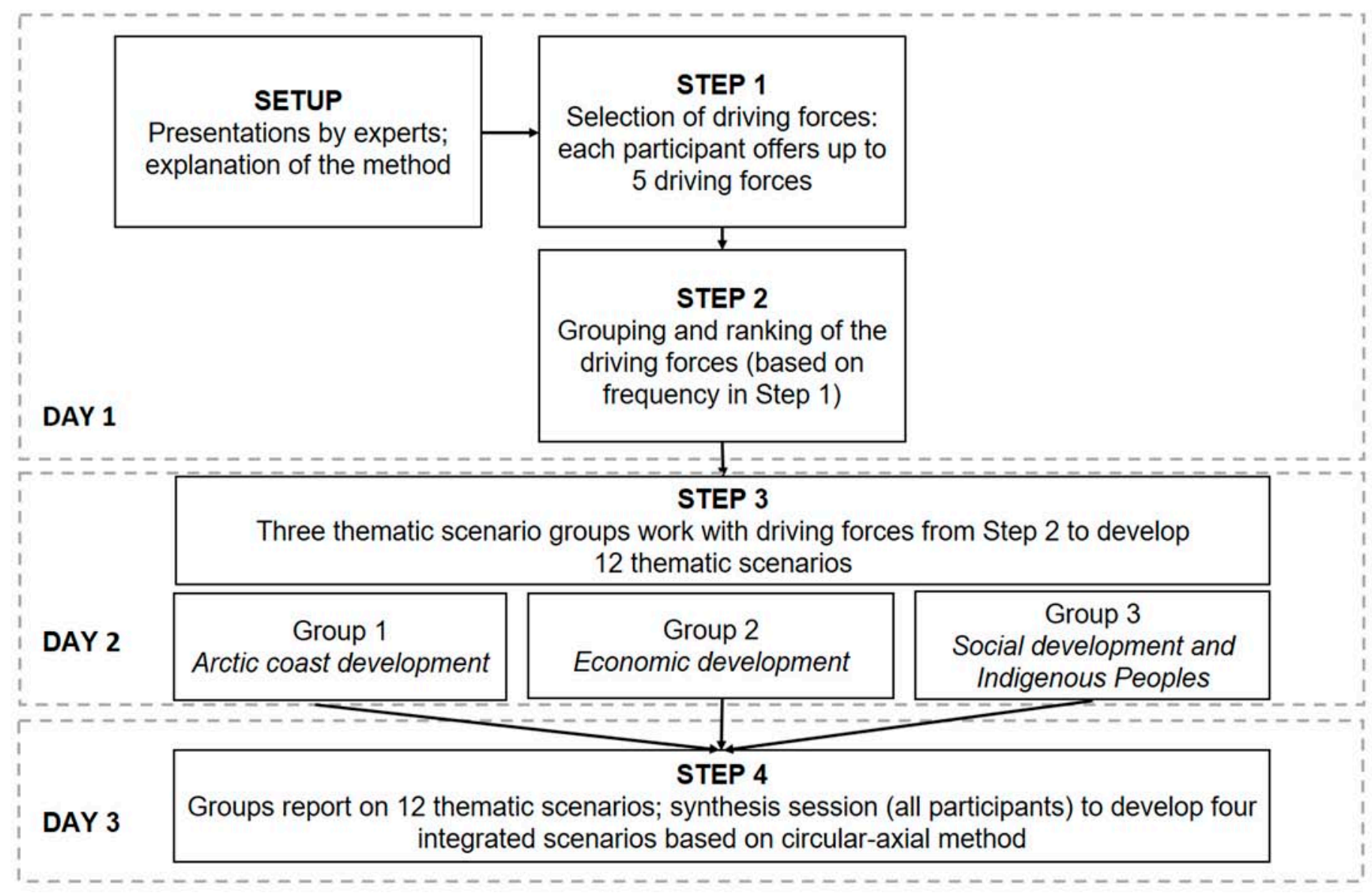

FIG. 1. Scenario workshop process flow chart.

and general forecasts related to climate change, Arctic shipping, economic development of the Russian Arctic, and demographic dynamics. These presentations set the stage for scenario development and ensured the participants' baseline knowledge level. Subsequently, the participants were asked to individually and anonymously formulate up to five of the most important driving forces (drivers, factors) for Arctic development by 2050 . We broadly interpreted drivers as underlying issues, events, processes, or trends with a high level of probability to "drive" future development in the Arctic (UNDP, 2015:28). All collected responses were sorted and divided by moderators into key clusters. In addition, the moderators identified the driving forces with the highest volume of submissions. The results were reported and described in detail to all participants. From 125 driving forces submitted by the participants, the moderators identified 14 clusters. The results of clustering were reported at the next session and accepted by unanimous consent. In the second stage, the participants were split into three thematic working groups. The first group worked on the scenarios for the Arctic coastal zone of Russia and the future of Arctic shipping in the context of climate change. The second group focused on economic development scenarios, and the third group was charged with looking into social development in the Russian Arctic and the future of the Indigenous Peoples.
The common objectives for all working groups were (1) based on the list of driving forces and their clusters created in the previous stage and through the process of open group discussion and voting, to identify at least two key driving forces most relevant for a given thematic group, and (2) using these key driving forces and applying the scenario axes method (van't Klooster and van Asselt, 2006; Brigham, 2008; Rounsevell and Metzger, 2010) to construct four Arctic scenarios in each working group. Altogether 12 scenarios were proposed by the three working groups and presented for a joint discussion in order to integrate them into four all-encompassing scenarios.

In the scenario-building exercise, we used the axes method, a standard method for scenario building (Brigham, 2008; Wesche and Armitage, 2014; Lovecraft et al., 2017a, b). It represents scenarios as the quadrants of two axes' intersection zones, where $\mathrm{X}$ and $\mathrm{Y}$ are the key factors (driving forces) of development. In so doing, the two ends of each axis designate opposite characteristics.

We further subcategorized the driving forces into internal (endogenous) or external (exogenous) to facilitate scenario development. Internal drivers include those that can be directly influenced by domestic economic actors and government authorities based on their priorities and strategies to make economic and social impacts. They are entirely or to a large extent regulated at the national, 
regional, or local levels (such as domestic policy, human capital development, etc.). External drivers, on the contrary, are generated primarily externally (e.g., oil and gas prices on the global market) and often act as a condition for or constraint on future development. National and local actors have very little or no ability to have an impact on these external forces. Considering this distinction, while creating a scenario axis, it may be desirable to identify one driver that we can influence, whereas another driver can be exogenous, acting as a contingent constraint.

The group also agreed to categorize the driving forces as "hard" and "soft." Hard forces include those with a material dimension, such as transport and telecommunications infrastructure, accumulated property, and capital assets. Soft drivers are less tangible factors associated with social and human capital, institutions, entrepreneurial capacity, and creativity of the local community. An important consideration for scenario building is to include and combine both internal and external as well as hard and soft driving forces.

Upon completing the thematic scenarios with the traditional axes matrix approach, we applied a newly developed method of circular-axial systematization that allowed us to aggregate all scenarios into one complex scenario matrix. The method was proposed and collectively designed by workshop participants and was one of the workshop outcomes (see detailed explanation in the Results section). The fundamental difference from standard axes matrix approaches is that, in the circular-axial systematization method, the common driver is presented not in the form of an axis but as a circle: the circle's outer ring embodies one development option, and the inner ring represents its opposite. This method works best when multiple scenarios have at least one common driving force. Then scenarios are combined using the intersection between the common driving force and other driving forces based on the scenarios' position along the axis's spectrum. The main advantage of this approach is that none of the original scenarios are lost or absorbed by others, and each is explicitly present in the final matrix. Most importantly, this approach allows conducting a synthesis to arrive at a limited number of integrated scenarios (in our case, four).

\section{SCENARIO-BUILDING RESULTS}

\section{Driving Forces for the Future Development of the Russian Arctic}

As part of the scenario-building process, we identified 14 clusters of driving forces affecting Arctic futures. Based on the number of submissions received from participants under each cluster, the driving forces were ranked as follows: international relations, technologies, domestic policy, climate, raw materials market, human capital development, infrastructure, traditional land use and Indigenous Peoples' culture, environmental protection, corporate social responsibility, tourism, sustainable development, rural agriculture, and health. The first six drivers were recognized as playing the most crucial role in shaping the futures of the AZRF. As a result of combining these key driving forces, working groups built four thematic scenarios for each three areas of Arctic development as described below.

\section{Scenarios for Arctic Coast Development}

Two relevant driving forces were determined for the thematic scenario of Arctic coast development in the context of Arctic shipping, environmental change, and international cooperation: domestic policy and international affairs (Fig. 2).

At the positive pole of the domestic policy axis, the state recognizes the importance and unique position of the Arctic region and is ready to invest both material and financial resources and support local initiatives. This axis's opposing end corresponds to the situation where the Arctic is deprioritized and is expected to adjust to organizational and technological standards, legal norms, and practices typical for the southern regions.

On the international affairs axis, the positive extreme assumes the improved political climate globally (including lifting Western sanctions on the Russian economy) coinciding with mutually beneficial international cooperation in the Arctic. The negative extreme implies the aggravation of the global political crisis, which spills over to the Arctic as well as increased military tensions, a Russia/NATO split in the Arctic, and curtailment of international cooperation (such as the Arctic Council and cross border cooperation).

The quadrants of this model are the four resultant scenarios: The Arctic 'Garden of Eden,' The Arctic Fortress, Deep Freeze, and Back to the Nineties (see Fig. 2).

1) The Arctic 'Garden of Eden': Under this scenario, both domestic and foreign policy dimensions are favorable for the development of the AZRF. The increased flow of Russian and foreign investment to the region is facilitated by lifted Western sanctions and the removal of Russian restrictions on foreign capital investment into strategic industries and the Arctic shelf exploration. The Northern Sea Route increasingly opens for both destination and transit shipping, and the Arctic freight volume is growing, primarily due to the export of hydrocarbons from the Arctic to other parts of Russia and abroad. The necessity to service these important commercial shipping flows of global significance facilitates intensified international collaboration in building new ports, including deep-water ports, multifaceted port facilities, maritime navigation and communication systems, search and rescue infrastructure, a management system for ship-generated waste and cargo residues, and medical aid stations. It also stimulates further improvement of the Russian ice-breaking fleet, including 


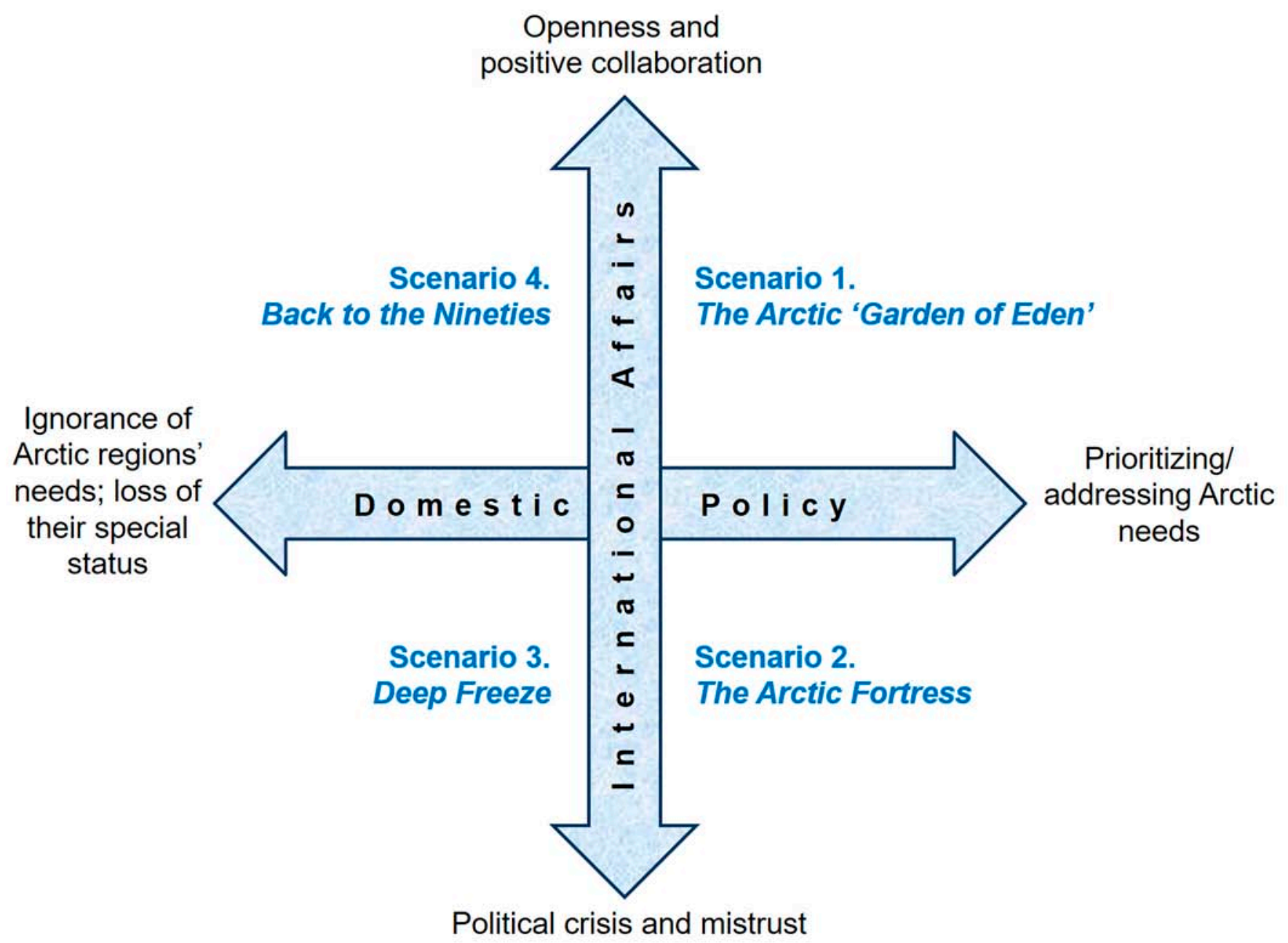

FIG. 2. Scenarios for Arctic coast development in the context of Arctic shipping, environmental change, and international cooperation.

nuclear-powered icebreakers. Domestic and inbound tourism, including cruise tourism, will become an increasingly important factor of regional development.

2) The Arctic Fortress: This scenario assumes that the Russian state is demonstrating heightened practical interest in the Arctic, yet it occurs in the context of an escalated confrontation with the West and worsening international tensions. In this perspective, the Arctic is perceived as a primarily "neutral zone" dividing Russia and the United States/NATO. In the face of dismantling international cooperation mechanisms (particularly relating to Arctic issues and arms control), increasing military capabilities of both Arctic and non-Arctic states elevate political sensitivities in the region. Western sanctions severely hamper the Russian Arctic shelf exploration and development. At the same time, China's position in the AZRF as an investor, a supplier of equipment, and a buyer (off-taker) of the extracted raw materials is strengthening and thus gives a strong impulse for bilateral cooperation on further infrastructure development and operation of the
Northern Sea Route as a destination shipping route. The Russian Arctic-Asia link acquires stronger international significance (Bennett, 2014).

3) Deep Freeze: In this scenario, the international political situation is highly unfavorable and aggravated by the fact that the Russian authorities express no interest in the Arctic issues, essentially leaving this region to its own devices. The Arctic is becoming Russia's "backyard." Development is limited to the implementation of individual plans and megaprojects related to military construction and raw materials extraction as well as the export of oil, natural gas, and metals. Local communities are not well integrated into the industrial employment market, and many of them are left behind with very few benefits from these economic activities. Such a political environment is highly favorable for Chinese investors, and Chinese businesses expand their presence in the Russian Arctic, pursuing natural resources and the Polar Silk Road opportunities. Commercial shipping operations are essentially limited to servicing these Russian-Chinese projects. 
4) Back to the Nineties: The $1990 \mathrm{~s}$ is the period of the ongoing dismantling of the Soviet economy, and industrial complexes followed the Soviet Union's collapse in 1991 (Heleniak, 1999; Hill and Gaddy, 2003). Improving relations between the Western countries and Russia lead to "internationalization" of the Russian Arctic. The Russian state remains mostly passive and uncommitted in its Arctic regions, which are left without major interventions and state investments. The region's economic development is based on the principle of predatory exploitation of its natural resources by both domestic and foreign companies. Economic expansion in the Russian Arctic mostly originates from China and competing Western countries. Shipping services are expanding along the Northern Sea Route, which is subsidized by the Russian state. New cruise shipping opportunities are opening, and the tourism industry is booming in the region.

\section{Economic Development Scenarios}

An important element for constructing an economic development scenario is a balanced combination of external and internal driving forces. The working group chose the global raw materials market (the value of natural resources in the global market) as an external driver. A domestic economic policy (a combination of federal economic policies regarding the Arctic, regional programs of regional economic development and, to a lesser extent, municipal authorities' development efforts) was identified as the primary internal driving force.

The significance of the raw materials market for the economic development of the Arctic regions is evidenced by the entire history of Russia's northern development and was equally valid under the Soviet economic regime (Kotlyakov and Agranat, 1994; Hill and Gaddy, 2003; Gritsenko and Efimova, 2020). The domestic policy's role has always been defining in the Arctic due to the strong involvement of the Soviet and Russian state with a willingness and capacity to control and use the territories (Petrov, 2018).

The resultant four economic development scenarios are presented in Figure 3: Golden Regions, Arctic Dragons, Ghost Towns, and Corporate Islands.

5) Golden Regions: This scenario is characterized by a favorable conjuncture of the natural resources world market and strong Arctic-oriented domestic policies both at the federal and regional levels. Its primary features include rapid growth of wealth and wellbeing of local populations, generous social programs, and cooperative relationships between the regional authorities and large resource companies. However, under this scenario, the traditional natural-resource-based economy (e.g., via the "resource curse") may cause a risk of imbalances in economic and social development and lead to longterm instability (rapid economic growth is inevitably accompanied by the uneven distribution of wealth and growth of social inequality). In addition, this scenario may entail a loss of incentives for innovation, new environmental risks due to the rapid expansion of natural resource exploration and extraction areas, and precipitous growth of interregional mobilities, when short-term and long-term labor migration contribute to fast cultural, religious, and ethnic transformations of the Russian Arctic.

6) Corporate Islands: This scenario reflects a combination of a favorable situation for the Russian resource-based economy and a very weak domestic policy in relation to the Arctic, which is inevitably accompanied by the natural resource grab of the most economically attractive enclaves by foreign companies and international corporations. It is fair to say that this is a very unfavorable scenario for Russian national security and national interests in general, particularly for the Arctic regions' economic priorities, which are dominated by rent-seeking powerful political actors with affiliated smaller business entities. Bound together, they heavily contribute to establishing a corrupt atmosphere and formation of a single-industry economy, a likely victim of the resource curse. According to this scheme, labor is brought in from abroad or less developed southern regions of Russia. Regional and local authorities make no effort to support human and cultural capital or invest in innovative technologies, a knowledge-based economy, and social infrastructure. Consequently, this scenario carries serious economic, social, and environmental risks and a high level of instability. In fact, it contains a built-in self-destruction mechanism and cannot last for a long time. Rapidly depleting natural resources due to the irresponsible management practices and the predominantly profit-oriented policies of the authorities and business actors will eventually lead to large corporate players' loss of interest in the territory, thus ending this scenario.

7) Ghost Towns: This scenario contains an interesting dialectical contradiction by integrating both unfavorable global market conditions and a weak domestic policy towards the Arctic. On the one hand, it is accompanied by massive population outflows, economic contraction, and possible recession, feeding the atmosphere of desolation from growing unemployment rates and decaying industrial and social infrastructure. On the other hand, in this scenario, the role and significance of the Indigenous Peoples' traditional lifestyle with their reliance on subsistence economy as well as traditional values and environmentally sustainable practices are increasing. In contrast to economic growth that is often accompanied by territorial consolidation, the multifaceted socioeconomic decay is characterized by the fragmentation of the Russian Arctic into various zones of depression, each struggling alone and looking for its own survival strategies in a harsh reality. 
Arctic-oriented policies; an emergence of a knowledge-based economy

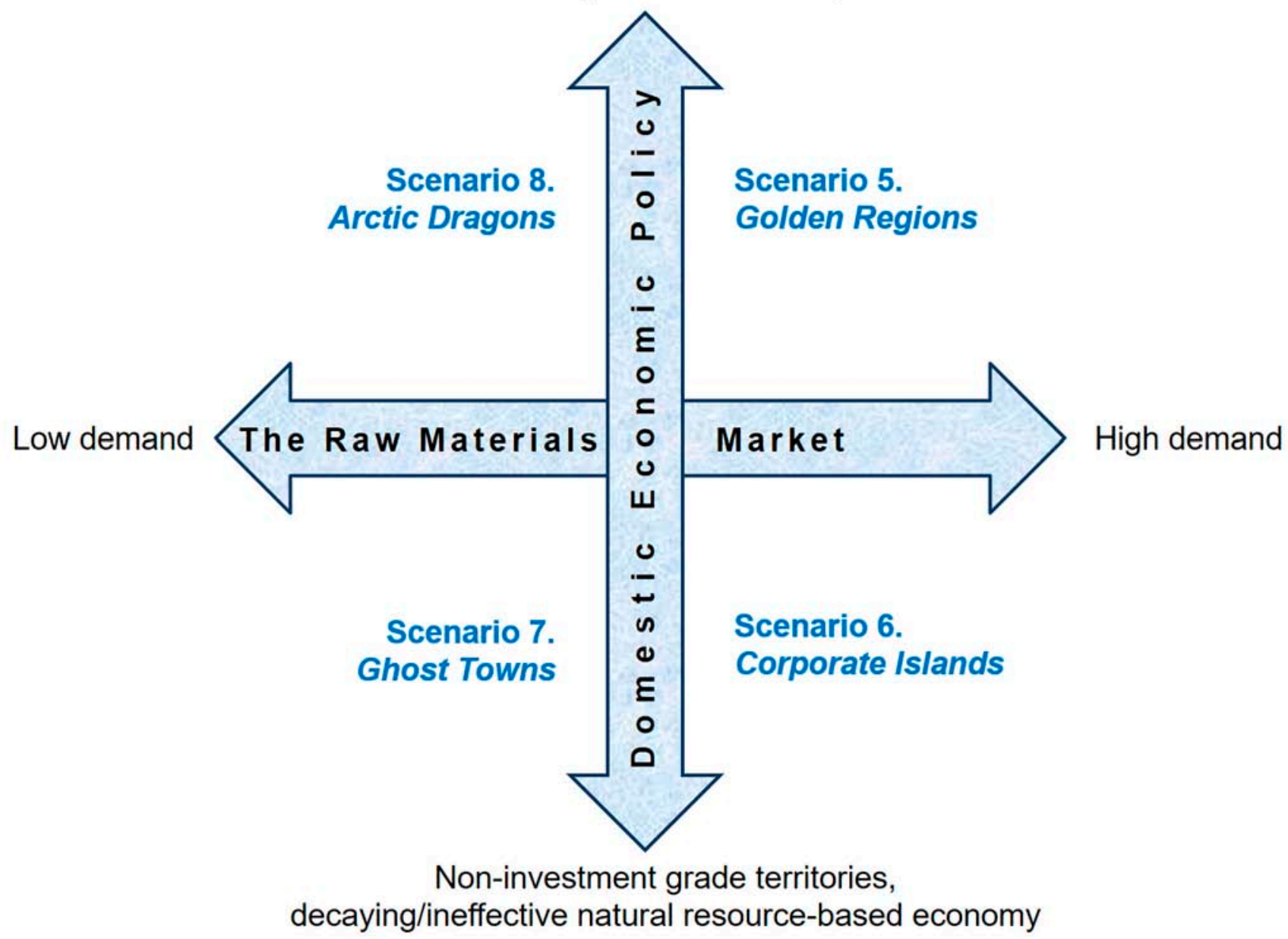

FIG. 3. Arctic economic development scenarios.

8) Arctic Dragons: This scenario is characterized by an exceptionally favorable domestic policy regarding the Arctic, against the backdrop of adverse conditions in the global natural resources market. Poor market conditions spur economic diversification in Russia's Arctic and facilitate a fundamental economic shift towards a knowledge-based economy with the emphasis on building a circular economy, knowledge- and technology-intensive industries, creation of closedloop industrial waste management systems, support of business innovation centers, and transfer of new technologies to Arctic economy as well as the growth of the service sector (e.g., tourism). The introduction of innovative technologies allows the implementation of large-scale projects with minimized environmental impacts and reduction of existing pollution (e.g., efficient waste processing). This scenario is also directed to improving living standards and building infrastructure. Over time, regional economic disparity among Russian Arctic regions and social inequality within them are gradually reduced. In terms of incentives for economic diversification and modernization, this is the most positive scenario for the Russian Arctic's further economic development.

\section{Social Development and Indigenous Peoples' Futures Scenarios}

In the scenarios of social development, the emphasis was on changes in the living conditions and the role of the Indigenous Peoples. In times of globalization and climate change in the Arctic, traditional ways of life are exposed to technological, environmental, and economic transformations (Fondahl et al., 2015). Nevertheless, the resilience of Indigenous communities may provide new insights into sustainable development (Fondahl and Wilson, 2017; Graybill and Petrov, 2020).

With a strong focus on policies and programs aimed at Arctic Indigenous Peoples and technologies, domestic social policies were chosen as the most important driving forces of social development in the Arctic through 2050. Technologies related to accessibility and communication were considered the most crucial. These included satellite and cell phones, Internet, off-road vehicles, light aircraft, 

Prioritizing/addressing all Arctic residents' needs;
support of traditional land use

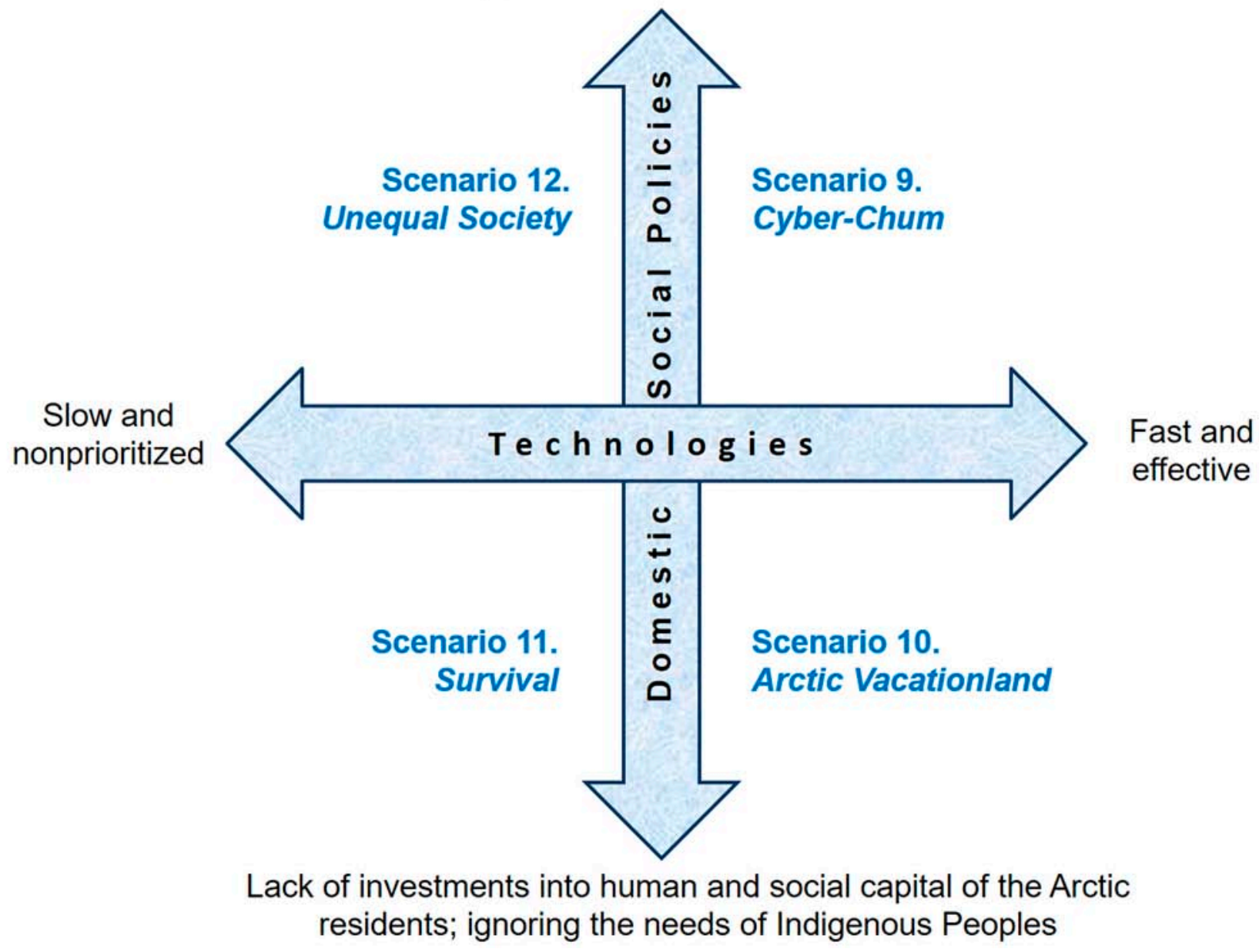

FIG. 4. Arctic social development scenarios.

riverboats, and small sea vessels, among others. Access to educational resources by Indigenous Peoples, including nomadic communities, was also recognized among the key priorities in domestic social policies. Improving the current compulsory educational system for Indigenous children that is largely based on boarding schools and a limited number of nomadic kindergartens where Indigenous students are prepared for boarding schools is another important element for future planning. The new system will guarantee high-quality education tailored to Indigenous Peoples' needs, while providing opportunities for Indigenous youth to continue education if desired. A focus on public administration as part of Indigenous education would help establish an effective local self-governance system at the municipal level. This practice-oriented system could become an important factor in determining the Arctic's future development.

The following four scenarios were created for social development in the Russian Arctic: Cyber-Chum, Arctic Vacationland, Survival, and Unequal Society (Fig. 4).
9) Cyber-Chum: Named after a dwelling (chum) used by the Indigenous Peoples in the Russian North, the CyberChum scenario is the most positive one in this matrix. It assumes the active technological development and full attention of the federal and regional authorities to Indigenous Peoples' interests, cultures, traditional land use, and way of living. New technologies, such as robotics, may become trendy in the Arctic and provide more comfortable living standards (heating, Internet access, water supply, delivery services, etc.) and be used to replace manual labor. These robots (for instance, drones) may make deliveries, track and potentially herd the reindeer. This scenario also ensures the availability of medical care and services (including telemedicine and highly developed self-help first-aid skills) as well as accessible education for Indigenous communities (including distance education at any level). However, this scenario poses some risks. Among them is the increased vulnerability of remote communities due to their overreliance on communication and other technologies at the expense of Indigenous knowledge and traditional survival skills. There are also new risks associated with 
TABLE 1. Driving forces in the proposed scenarios. (Authors' aggregation approach based on the joint group discussions.)

\begin{tabular}{|c|c|c|}
\hline Working groups/Thematic scenarios & Driver 1 & Driver 2 \\
\hline $\begin{array}{l}\text { Arctic coast development in the context of Arctic shipping, environmental change, } \\
\text { and international cooperation }\end{array}$ & Domestic policy & International affairs \\
\hline Social change, human capital, and Indigenous Peoples' livelihoods & & Technologies \\
\hline
\end{tabular}

high accessibility and robotization that might negatively affect Indigenous Peoples' health, such as an inactive lifestyle and increased consumption of more accessible unhealthy food.

10) Arctic Vacationland: This scenario implies a widespread development of mobility technologies (making the Arctic more accessible), while weak domestic policies do not support traditional livelihoods and a subsistence economy. The development of tourism is viewed as a key economic driver in which the Indigenous Peoples find themselves serving tourists, making souvenirs, and demonstrating traditional skills and practices. Tourism development provides a relatively high and stable income for Indigenous Arctic communities, but the traditional way of life, Indigenous knowledge, and land-use practices are disappearing. The concentration of population near tourist destinations may lead to pasture overgrazing with increasing reindeer losses and the abandonment of the nomadic way of life. Tourist-oriented and often simplified or standardized market-driven souvenir production lead to the degradation of authentic craft skills and add to ongoing cultural loss. Indigenous People not involved in the tourism industry face a challenging future. Some communities may experience growing rates of alcoholism, suicide, and other social issues associated with economic marginalization and identity crisis.

11) Survival: This scenario describes the existence of the Arctic Indigenous population on the verge of survival when neither government nor technologies are there to support development. The lack of strong domestic policy means that the federal and regional governments do not invest significant efforts in developing the North. As a result, environmental degradation, poaching, and other illegal environmental practices are occurring. The rural population in remote areas is declining. Meanwhile, the government's attempts to implement relocation assistance programs in order to move Indigenous and local residents from tundra and remote villages to towns and cities exacerbate the loss of identity and increase social and health risks for displaced inhabitants. However, some Indigenous communities with strong internal capacities can successfully maintain traditional livelihoods based on a subsistence economy.

12) Unequal society: This scenario incorporates strong supportive policies with respect to Indigenous Peoples' land use and ways of living coupled with no investments in transportation technologies and infrastructure. Many remote areas remain isolated. As a result, the development of the Arctic becomes increasingly uneven and leads to sharp social differentiation. In the mineralrich regions, extractive companies may implement various forms of benefit sharing with the local Indigenous population, such as hiring locals as unskilled workers and using local subcontractors and suppliers. However, in other areas situated away from extractive industry, Indigenous and local communities remain marginalized with a limited ability to engage in the wage and mixed economies. The socioeconomic and cultural gaps may thus increase drifting communities and Arctic regions apart.

\section{Developing Integrated Scenarios}

Ultimately, we aimed at designing integrated, overarching future pathways based on synergies among individual scenarios. This synthesis will allow policymakers and other stakeholders to have a more multifaceted and complete picture for developing strategies for the AZRF. Therefore, in the process of integrating 12 thematic scenarios, we focused on finding elements of convergence among them. As can be seen from the descriptions above, the working groups identified and largely agreed on the key driving forces that will most likely affect the Russian Arctic. They singled out a total of four major drivers: domestic policy, technologies, global resource markets, and international affairs (Table 1).

Out of these, domestic policy was a part of all 12 scenarios. Having one common axis permitted the group to implement the circular-axial systematization method to arrive at four mega-scenarios without losing details of the original ones.

Figure 5 shows the circular-axial systematization of the 12 thematic scenarios. By using this visualization and the underlying circular-axial method, it was possible to formulate four integrated scenarios for the Russian Arctic until 2050, metaphorically called Harmonious Arctic, SelfReliant Arctic, Resource-Dependent Arctic, and Forgotten Arctic.

The Harmonious Arctic scenario includes three thematic scenarios: (1) The Arctic 'Garden of Eden,' (5) Golden Region, and (9) Cyber-Chum. Despite Arctic resources being in high demand on the global raw materials market, Russian state policies encourage bottom-up innovation and creativity. With the support of the authorities, 


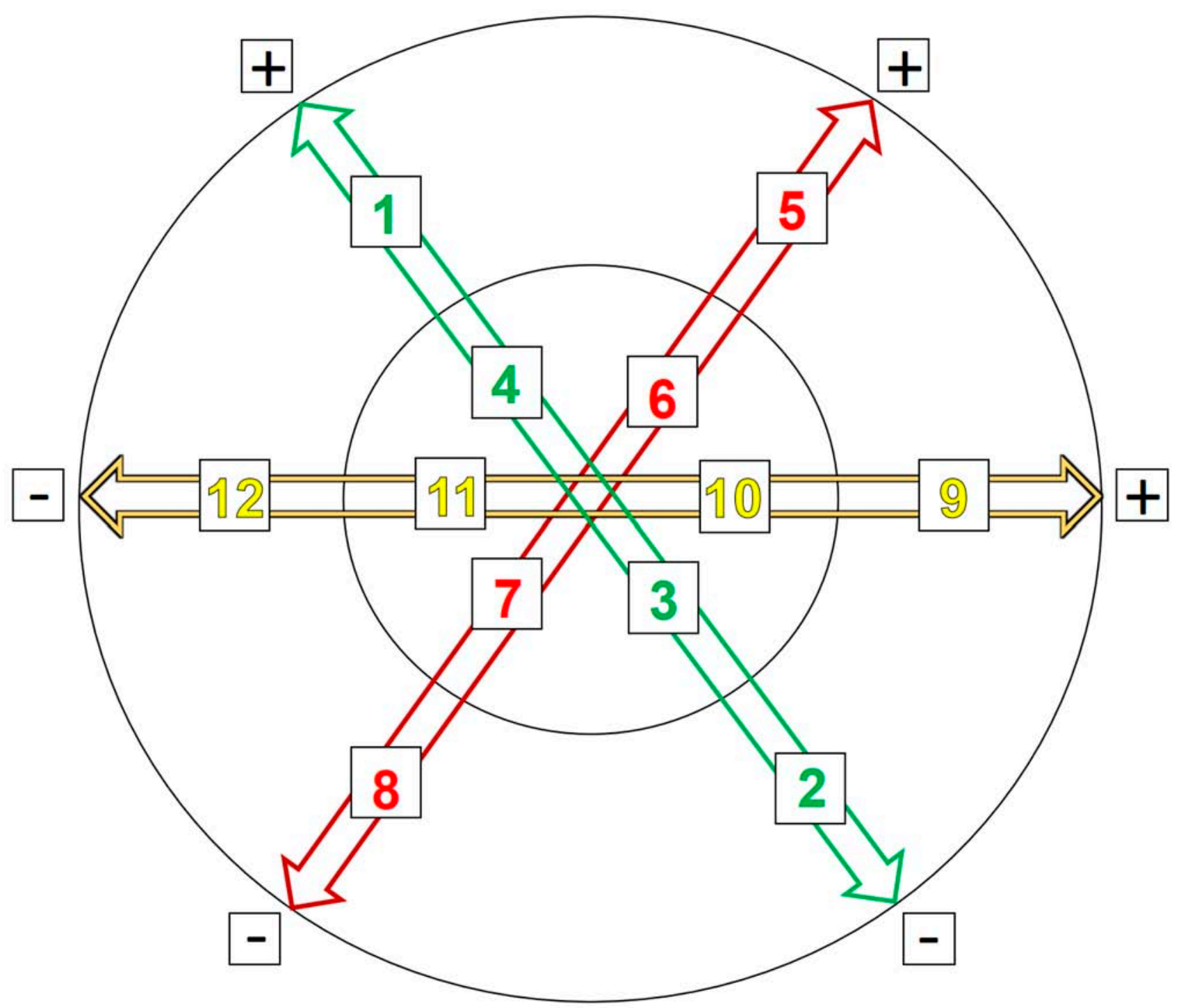

FIG. 5. Circular axis chart for Arctic development scenarios. The circle presents a domestic policy driver, i.e., the Russian Federation's state (federal) policy aimed at the Arctic regions' development and the regional policies of the Arctic federal subjects (federation's constituent units-regions). The outer ring of the circle is a domestic policy aimed at developing the Arctic, including its economy, social sphere, shipping and trade, and the support of Indigenous traditional land use and way of life. The inner ring is domestic policy that is not focused on the Russian Arctic development. Arrows present the "hard" external (exogenous) driving forces: yellow arrow - technological development; green arrow - international affairs; and red arrow - global resources markets. Squares outside the circle present opposite characteristics of two ends of each axis: [+] favorable conditions; [ -$]$ unfavorable conditions. The numbered squares refer to the 12 thematic scenarios: [1] The Arctic 'Garden of Eden,' [2] The Arctic Fortress, [3] Deep Freeze, [4] Back to the Nineties, [5] Golden Regions, [6] Corporate Islands, [7] Ghost Towns, [8] Arctic Dragons, [9] Cyber-Chum, [10] Arctic Vacationland, [11] Survival, and [12] Unequal Society.

large-scale megaprojects are being implemented alongside a growing network of local actors (subcontractors, service companies, cultural and scientific organizations, etc.); this implementation allows the maximization of local multiplier effects.

The Self-Reliant Arctic scenario includes thematic scenarios (2) Arctic Fortress, (8) Arctic Dragons, and (12) Unequal Society, which collectively represent a strong domestic policy aimed at developing the Arctic against the backdrop of unfavorable resource, international, and technological conditions. Arctic natural resources are either not in high demand or their extraction and sales are limited (e.g., by external sanctions). Technological advances are slow and international relations are not conducive to development. Socioeconomic disparity among different Arctic regions is widening as is income inequality among Arctic residents. Since reliance on the resource economy is not possible, Arctic businesses and residents seek new opportunities to spur economic development through non-extractive tertiary and quaternary sectors and entrepreneurship with the state support. As an outcome, innovative industries with efficient technologies, new types of businesses, and cultural and knowledge economies are emerging.

The Resource-Dependent Arctic scenario includes weak domestic policies accompanied by positive international 
RUSSIAN ARCTIC INTEGRATED SCENARIOS • 317

cooperation trends, the availability of new technologies, and high global demand for raw materials. It is a combination of thematic scenarios (4) Back to the Nineties, (6) Corporate Islands, and (10) Arctic Vacationland. Under the ResourceDependent Arctic, the northern regions are considered almost exclusively a natural resource base suitable for exploitation to ensure the constant supply of raw materials for export. Arctic regions not covered by the "export rush" experience a deep economic crisis; socioeconomic polarization within the Arctic is rapidly growing. The Russian Arctic is dominated by large (state-owned, private domestic, or foreign) industrial corporations, often saturated with foreign direct investments. Environmental protection regulations are weak. The implementation of large projects is predominantly controlled by monopolists. Local innovation development is virtually absent; both technologies and a significant portion of the labor force are imported from abroad and outside the Arctic zone. However, the state is committed to making targeted investments and providing welfare for Arctic residents. State policies subsidize social payment and education systems; at the same time, finance programs encourage local economic initiatives. Creative grassroots initiatives from local small- and medium-sized businesses cannot find investors or funding from the authorities and mainly function at a very small scale. Positive effects may only be felt in selected resource regions and economic spheres (for instance, Arctic tourism and Indigenous entrepreneurship) or where companies improve transportation accessibility and maintain emergency services.

The Forgotten Arctic scenario was deemed by the workshop participants the least desirable. It incorporates thematic scenarios (3) Deep Freeze, (7) Ghost Towns, and (11) Survival. In the Forgotten Arctic, natural resources are in little demand or the prices of raw materials are low, the demand for maritime transportation is insignificant, and technology and infrastructure are not improving amid poor international relations. These conditions are exacerbated by weak domestic policies or the absence of state resources to support Arctic development. Given the lack of economic benefits from the Arctic, the Russian state loses interest in northern development, mostly leaving it to its own devices. The importance of government agencies that have access to the state budget is growing. Stagnation tendencies are worsening in all spheres of economic, cultural, social, and political life. The outflow of the Arctic population is increasing. Although the pressure on the environment declines, abandoned settlements, industrial and military facilities create new environmental problems, as does previously accumulated waste. Indigenous Peoples return to their traditional nature management practices and subsistence economy, which become more viable than single-industry urban settlements.

\section{DISCUSSION AND CONCLUSIONS}

This paper describes the process and outcomes of the scenario-building exercise conducted by a diverse group of experts, policymakers, and other stake-, rights- and knowledge-holders. The resultant 12 thematic and four integrated scenarios describe possible futures of AZRF through 2050. The collaborative, participatory scenariomaking process focused on describing the most plausible futures helps recognize the drivers of change, identify possible options for development, and select strategic approaches necessary to implement the most favorable scenarios.

The four integrated scenarios represent distinct paths of development for the Arctic regions of Russia-from an optimistic Harmonious Arctic signified by favorable external and internal drivers to a doomsday Forgotten Arctic when northern regions suffer from neglect and economic uncertainty. Intermediate scenarios, such as SelfReliant and Resource-Dependent Arctic, illustrate options when conditions are mixed. Although these scenarios may be seen as introducing rather generalized dichotomies, they are useful as broadly written strategic outlines of potential futures over the next $25+$ years. They entail certain choices and options regarding regional development and, coupled with more nuanced thematic scenarios, can benefit strategic policymaking. For example, investing in local capacities, human capital, and entrepreneurship seem to be effective policy tools regardless of how external factors such as global markets and international relations are unfolding. In contrast, overreliance on the resource sector may lead to negative outcomes even under the right market conditions.

The scenario-building experience also revealed some interesting points for further discussion. First of all, the circular-axial scenario systematization method developed in the course of this workshop proved to be a powerful technique to create integrated visions of the future and was deemed useful by the workshop participants. Many in the group were concerned that the original 12 "axes" scenarios, while valuable separately, would have been too many to be of use or interest to policymakers. They were also unable to intersect various spheres of Arctic life described by the themes. The final circular-axial design also allowed a deeper understanding of the development options by pointing to commonalities and differences among the original 12 scenarios. By incorporating multiple variables while providing opportunities for synthesis, the circularaxial method was able to address the major limitation of the standard axes technique, which accounts for only a limited number of axes and drivers at a time (Beach and Clark, 2015; Nilsson et al., 2017a; Nilsson et al., 2019). Its main shortcoming, however, is its reliance on the availability of a common axis (in this case, domestic policies) to integrate the scenarios.

The participatory, bottom-up approach used in this study implied the active and open involvement of all workshop attendees who were encouraged to freely share their 
knowledge (Kok et al., 2006). Unlike framework-scenario building (O'Neill et al., 2014), our approach avoided preconceived framings and relied on participants' own visions of the future. The workshop worked to maximize individual contributions through an open dialogue that promoted the independence of thoughts, approaches, and opinions. However, the four integrated scenarios developed for the AZRF could themselves be used as a framework for scenarios development in individual regions of the Russian Arctic utilizing a combined participatory bottom-up and top-down methodology already tested in the Barents region (Nilsson et al., 2015, 2017a; Klyuchnikova et al., 2017).

One important aspect revealed by the scenarios is the clear emphasis on domestic policies and the role of government institutions in the Russian Arctic. All thematic scenarios included government policies as one of the two driving forces. The focus on domestic policies (economic, social, etc.) is not surprising given the state's decisive role in developing the Russian Arctic (e.g., Petrov, 2018; Fondahl et al., 2020). However, it reveals the persistent state-dependency and, therefore, path-dependency of northern development in Russia. Under the same external circumstances (e.g., international affairs or global resource prices), the nature of a scenario can vary drastically subject to the domestic policies vector (cf. Self-Reliant Arctic vs. Forgotten Arctic). At the same time, domestic policy as a soft factor of development can be more easily managed (or manipulated) and thus presents a viable tool for moving towards the desired scenario. It is also remarkable that most scenarios appear to be rather inward-looking in a sense that workshop participants were primarily concerned with internal capacities and options, not external ones. This perspective is reflected by the selections of the key driving forces, and how the scenarios were designed by the groups.

Cooperation with key foreign players, namely the West and China, appears as a defining driver in the coastal zone and Arctic navigation scenarios. It also plays an important role in the integrated scenarios; for example, Harmonious Arctic assumes an improvement in international relations, while Self-Reliant Arctic considers continued or worsened tensions with the West. In contrast, under many scenarios, the role of China is elevated. China appears as an important off-taker of natural resources, a user of Arctic shipping, and an investor (regardless of whether Russia's domestic policies are strong or weak) or strategic partner. China's interest in Arctic raw materials in many ways underlines the global market conditions embedded in the scenarios. At the same time, the rampant natural resources grab by foreign actors, including China (as in the Resource-Dependent Arctic and especially in Corporate Islands scenarios), is considered very unfavorable for Russian national security and economic interests.

Overall, the driving forces identified for the Russian Arctic were in some ways similar yet distinct from the drivers described for other Arctic areas. In particular, Russian responses emphasized international relations, technology, domestic policies (governance), climate, human capital, the culture and economy of Indigenous Peoples, resource market conditions, and environmental protection. In the case of Greenlandic scenarios (Hansen and Larsen, 2014), for example, international relations and climate were not included by the study participants, who focused on education, communication, industrial development, governance, and societal adaptation, among others. In Russia, linking the Arctic's future to international relations seems to emanate from the perceived importance of foreign investments and economic sanctions to enable or impede economic development in the Russian Arctic. However, in both cases, investments in education and technology, as well as addressing the interests of Indigenous Peoples, were included as key driving forces.

Another notable observation is the absence of climate among the key drivers included in the scenarios. Although it was identified in the original set of 14 driving forces, none of the subsequent scenarios explicitly incorporated climate in the matrix. One explanation is that climate change was assumed to be happening in all scenarios but was considered a background trend rather than a driver. Another possibility is that the participants did not feel that climate change will play a defining role and can be mitigated by other factors, such as domestic policies. This situation contrasts with the scenarios for northern Sweden (Nilsson et al., 2015), where climate was deemed the most important driver, although the participants downplayed the impacts of climate change, noting their high uncertainty. Environmental protection was also not among the axes in any of our scenarios although it routinely appeared in scenario descriptions made by the groups and thus was considered more as a derivative of other factors than a strong driving force in its own right.

The scenarios described above are certainly not exhaustive, and they reflect the views of participants with broad expertise yet context-dependent and confined to Russia's Arctic regions (mostly Nenets Okrug), USA (Alaska), Sweden, and Norway. This said, our results compare well with scenarios elucidated in other parts of the Arctic where similar exercises have taken place (e.g., in Greenland; Hansen and Larsen, 2014). Although with the span of 50 years and only two driving forces included (oil production and education), the Greenland scenarios resemble some of the options discussed for the Russian Arctic. For instance, Greenland's Strong Polar Bear scenario resembles the Harmonious Arctic in our study, while the Lazy Walrus shares commonalities with the Forgotten Arctic scenario. Although differences are also evident (e.g., the overpowering role of domestic policies in the case of Russia), the convergence of these scenarios from very different parts of the Arctic is illuminating and suggests that interregional knowledge exchange between experts and policymakers would be productive.

Having an array of scenarios allows decision-makers and all stakeholders to consider possible alternative futures, both in respect to the overall direction of development and in terms of benefits or drawbacks for various stakeholder 
groups. Each alternative entails specific policy actions to direct the Arctic's development trajectory. If designed and implemented systematically, these actions will constitute a strategy. The results of this study were presented to the regional policymakers during the feedback session at the end of the workshop and shared with stakeholders and government entities to inform their efforts to create regional development programs in AZRF.

Although we cast a wide net to gather key groups at the table, a broader representation of the Arctic regions and stakeholder communities could have been instrumental and should be pursued in the future. Additionally, although Indigenous voices were part of this scenario exercise, Indigenous participants were represented in two groups focused on social and economic development. More extensive involvement of the Indigenous Peoples as well as other key local groups (e.g., youth) would be needed to strengthen the co-productive nature of the scenariobuilding process. Greater involvement must also be done to promote the level of influence by Indigenous Peoples and other underrepresented groups on Arctic policies. Having the Indigenous Peoples' leaders and regional policymakers at the same table has been one of this workshops' important achievements. At the same time, the presence of the Indigenous Peoples in the visioning exercises should not substitute their real voice in decision making but provide a platform for early inclusion of the perspective of Indigenous Peoples in defining strategies pursued in their homelands.

The development of more detailed regional scenarios and the inclusion of the novel scenario methodology and scenarios presented in this paper into national Arctic development policy frameworks, as well as a circumpolar comparison of regional and national scenarios, seem to be promising directions for further research and collaboration among experts, policymakers, and a wide range of stakeholders in the Arctic.

\section{ACKNOWLEDGEMENTS}

We would like to thank the Russian State Hydrometeorological University (RSHU), the Arctic Research Center ARCTICenter (University of Northern Iowa), the Arctic-COAST project (PLR \# 1441381), the Russian Association of Indigenous Peoples of the North Russian (RAIPON), the Nenets Indigenous Association 'Yasavey,' and the Administration of the Nenets Autonomous Okrug for invaluable support of this workshop. We also want to express our gratitude to the participants of the workshop for their efforts, insights, and invaluable contribution: Lawson Brigham (University of Alaska Fairbanks), Maksim M. Chuprov (The Assembly of Deputies of the Nenets Autonomous District), Maria A. Filippova (Nenets People Association 'Yasavey'), Andrey G. Gretsov (Herzen State Pedagogical University of Russia), Timothy Heleniak (Nordregio), Darya D. Karsonova (RSHU), Yury A. Khatanzeyskiy (Nenets People Association 'Yasavey'/RAIPON), Nikolay A. Kondratov (Northern (Arctic) Federal University (NArFU)), Petr A. Ledkov (Nenets People
Association 'Yasavey'), Valerii N. Malinin (RSHU), Aleksey A. Maslakov (Lomonosov Moscow State University), Arild Moe (Fridtjof Nansen Institute), Maria V. Monakhova (ARCTICenter, University of Northern Iowa), Aleksandr V. Potekhin (News Agency TASS), Alexander A. Saburov (NArFU), Viacheslav I. Shadrin (Institute for Humanities Research and Indigenous Studies of the North, Siberian Division of Russian Academy of Sciences/RAIPON/Yukaghir People Association of the Republic of Sakha (Yakutia)), Nikolay I. Shiklomanov (The George Washington University), Irina A. Sivobrova (NArFU), Olga S. Strepetilova (Department of Economic Development, Administration of the Nenets Autonomous Region), Anatoly N. Tokarev (Institute of Economics and Industrial Engineering of the Siberian Branch of the Russian Academy of Sciences), Maxim A. Vovchenko (Moscow Institute of Physics and Technology), and Yuri E. Yakovlev (Baltic-Arctic Marine Administration of the Federal Service for Supervision of Natural Resources). Finally, we are very grateful to the anonymous reviewers for their highly valuable comments and great ideas for future research directions. This workshop was supported by NSF under ArcticCOAST project (PLR \# 1441381). This research was conducted on the traditional lands and territories of the Arctic Indigenous Peoples.

\section{REFERENCES}

AMSA/PAME (Arctic Marine Shipping Assessment/Protection of the Arctic Marine Environment). 2008. The future of Arctic marine navigation in mid-century: Scenario narratives report. Arctic Marine Shipping Assessment of the Arctic Council's Protection of the Arctic Marine Environment Working Group. https://oaarchive.arctic-council.org/bitstream/ handle/11374/838/ACSAO-NO03_6_1_AMSA_Scenarios_ Future-Narratives_Report.pdf?sequence $=1 \&$ isAllowed $=\mathrm{y}$

Arbo, P., Iversen, A., Knol, M., Ringholm, T., and Sander, G. 2013. Arctic futures: Conceptualizations and images of a changing Arctic. Polar Geography 36(3):163 - 182. https://doi.org/10.1080/1088937X.2012.724462

Beach, D.M., and Clark, D.A. 2015. Scenario planning during rapid ecological change: Lessons and perspectives from workshops with southwest Yukon wildlife managers. Ecology and Society 20(1): 61.

https://doi.org/10.5751/ES-07379-200161

Bennett, M.M. 2014. North by northeast: Toward an Asian-Arctic region. Eurasian Geography and Economics 55(1):71-93. https://doi.org/10.1080/15387216.2014.936480

Berkhout, F., Hertin, J., and Jordan, A. 2002. Socio-economic futures in climate change impact assessment: Using scenarios as 'learning machines.' Global Environmental Change 12(2):83-95. https://doi.org/10.1016/S0959-3780(02)00006-7

Biggs, R., Raudsepp-Hearne, C., Atkinson-Palombo, C., Bohensky, E., Boyd, E., Cundill, G., Fox, H., et al. 2007. Linking futures across scales: A dialog on multiscale scenarios. Ecology and Society 12(1): 17. https://doi.org/10.5751/ES-02051-120117 
Blakkisrud, H. 2019. Governing the Arctic: The Russian State Commission for Arctic Development and the forging of a new domestic Arctic policy agenda. Arctic Review 10:190-216. https://doi.org/10.23865/arctic.v10.1929

Bourmistrov, A., Mellemvik, F., Bambulyak, A., Gudmestad, O., Overland, I., and Zolotukhin, A., eds. 2015. International Arctic petroleum cooperation: Barents Sea scenarios. Abingdon, Oxon: Routledge.

Brigham, L.W. 2008. Arctic shipping scenarios and coastal state challenges. WMU Journal of Maritime Affairs 7(2):477-484. https://doi.org/10.1007/BF03195146

Chaudhury, M., Vervoort, J., Kristjanson, P., Ericksen, P., and Ainslie, A. 2012. Participatory scenarios as a tool to link science and policy on food security under climate change in East Africa. Regional Environmental Change 13:389-398. https://doi.org/10.1007/s10113-012-0350-1

Falardeau, M., Raudsepp-Hearne, C., and Bennett, E.M. 2019. A novel approach for co-producing positive scenarios that explore agency: Case study from the Canadian Arctic. Sustainability Science 14:205-220. https://doi.org/10.1007/s11625-018-0620-z

Federal Law. 2014. O strategicheskom planirovanii v Rossiyskoy Federatsii [On strategic planning in the Russian Federation]. June 28, 2014. No. 172.

Flynn, M., Ford, J.D., Pearce, T., Harper, S.L., and IHACC Research Team. 2018. Participatory scenario planning and climate change impacts, adaptation and vulnerability research in the Arctic. Environmental Science \& Policy 79:45-53. https://doi.org/10.1016/j.envsci.2017.10.012

Fondahl, G., and Wilson, G.N., eds. 2017. Northern sustainabilities: Understanding and addressing change in the circumpolar world. Berlin: Springer.

Fondahl, G., Filippova, V., and Mack, L. 2015. Indigenous Peoples in the new Arctic. In: Evengård, B., Larsen, J.N., and Paasche, Ø., eds. The new Arctic. Berlin: Springer. 7-22.

Fondahl, G., Espiritu, A.A., and Ivanova, A. 2020. Russia's Arctic regions and policies. In: Coates, K.S., and Holroyd, C., eds. The Palgrave handbook of Arctic policy and politics. Cham, Switzerland: Palgrave MacMillan. 195-216.

Gidley, J.M. 2017. The future: A very short introduction. Oxford: Oxford University Press.

Gong, M., Lempert, R., Parker, A., Mayer, L.A., Fischbach, J., Sisco, M., Mao, Z., Krantz, D.H., and Kunreuther, H. 2017. Testing the scenario hypothesis: An experimental comparison of scenarios and forecasts for decision support in a complex decision environment. Environmental Modelling \& Software 91:135-155.

https://doi.org/10.1016/j.envsoft.2017.02.002

Graybill, J.K., and Petrov, A.N., eds. 2020. Arctic sustainability, key methodologies and knowledge domains: A synthesis of knowledge I. Abingdon, Oxon: Routledge.

Gritsenko, D., and Efimova, E. 2020. Is there Arctic resource curse? Evidence from the Russian Arctic regions. Resources Policy 65: 101547.

https://doi.org/10.1016/j.resourpol.2019.101547
Haavisto, R., Pilli-Sihvola, K., Harjanne, A., and Perrels, A. 2016. Socio-economic scenarios for the Eurasian Arctic by 2040. Helsinki: Finnish Meteorological Institute.

https://helda.helsinki.fi/bitstream/handle/10138/160254/ 2016nrol.pdf?sequence $=1$ \&isAllowed $=y$

Haigh, N. 2019. Scenario planning for climate change: A guide for strategists. New York: Routledge.

Hansen, A.M., and Larsen, S.V. 2014. Use of scenarios and strategic planning to explore an uncertain future in Greenland. Regional Environmental Change 14(4):1575-1585. https://doi.org/10.1007/s10113-014-0593-0

Heleniak, T. 1999. Out-migration and depopulation of the Russian North during the 1990s. Post-Soviet Geography and Economics 40(3):155-205.

https://doi.org/10.1080/10889388.1999.10641111

Hill, F., and Gaddy, C. 2003. The Siberian curse: How Communist planners left Russia out in the cold. Washington, D.C.: Brookings Institution.

Jacobsen, R.B., Langen, P.L., and Mosbech, A. 2017. Regional framework scenarios. In: Adaptation actions for a changing Arctic: Perspectives from the Baffin Bay/Davis Strait region. Oslo: Arctic Monitoring and Assessment Programme (AMAP). $97-100$.

https://www.amap.no/documents/download/3015/inline

Kahane, A. 2012. Transformative scenario planning: Working together to change the future. San Francisco, California: Berrett-Koehler.

Kahn, H., and Weiner, A.J. 1967. The year 2000: A framework for speculation on the next thirty-three years. New York: Macmillan.

Karlsdottir, A., Olsen, L.S., Harbo, L.G., Jungsberg, L., and Rasmussen, R.O. 2017. Future regional development policy for the Nordic Arctic: Foresight analysis 2013-2016. Nordregio Report 2017:1. Stockholm: Nordregio.

https://www.diva-portal.org/smash/get/diva2:1069494/ FULLTEXT01.pdf

Klimenko, E. 2014. Russia's evolving Arctic strategy: Drivers, challenges and new opportunities. Solna: Stockholm International Peace Research Institute.

https:/www.sipri.org/publications/2014/sipri-policy-papers/ russias-evolving-arctic-strategy-drivers-challenges-and-newopportunities

Klyuchnikova, E.M., Isayeva, L.G., Masloboyev, V.A., Aliyeva, T.E., Ivanova, L.V., and Kharitonova, G.N. 2017. Stsenarii razvitiya klyuchevykh otrasley ekonomiki Murmanskoy oblasti v kontekste global'nykh izmeneniy v Arktike [Scenarios for the development of key sectors of the Murmansk Region's economy in the context of global changes in the Arctic]. Arktika: Ékologiyâ i Ékonomika [Arctic: Ecology and Economy] 1(25):19-32.

Kok, K., Rothman, D.S., and Patel, M. 2006. Multi-scale narratives from an IA perspective: Part I. European and Mediterranean scenario development. Futures 38(3):261-284.

https://doi.org/10.1016/j.futures.2005.07.001 
Kok, K., Biggs, R., and Zurek, M. 2007. Methods for developing multiscale participatory scenarios: Insights from southern Africa and Europe. Ecology and Society 13(1): 8. https://doi.org/10.5751/ES-01971-120108

Konyshev, V., Sergunin, A., and Subbotin, S. 2017. Russia's Arctic strategies in the context of the Ukrainian crisis. The Polar Journal 7(1):104-124.

https://doi.org/10.1080/2154896X.2017.1335107

Kotlyakov, V.M., and Agranat, G.A. 1994. The Russian North: Problems and prospects. Polar Geography and Geology 18(4):285-295. https://doi.org/10.1080/10889379409377552

Lovecraft, A.L., and Eicken, H., eds. 2011. North by 2020: Perspectives on Alaska's changing social-ecological systems. Fairbanks: University of Alaska Press.

Lovecraft, A.L., Fresco, N., Cost, D., Blair, B. 2017a. Northern Alaska Scenarios Project report: Creating healthy, sustainable communities in Arctic Alaska. Fairbanks: University of Alaska Fairbanks.

https://www.searcharcticscience.org/files/page/documents/ 28065/nasp_report_2017_small.pdf

Lovecraft, A.L., Preston, B.L., Absar, S.M., Blair, B., Cost, D., Ernst, K.M., Fresco, N., et al. 2017b. Scenarios thinking for the Bering-Chukchi-Beaufort region. In: Adaptation actions for a changing Arctic: Perspectives from the Bering-ChukchiBeaufort region. Oslo: Arctic Monitoring and Assessment Programme (AMAP). 217-238.

https://www.amap.no/documents/download/2993/inline

Martelli, A. 2014. Models of scenario building and planning: Facing uncertainty and complexity. New York: Palgrave Macmillan.

Miles, I., Saritas, O., and Solokov, A. 2016. Foresight for science, technology and innovation. Cham, Switzerland: Springer.

Nicolis, G., and Prigogine, I. 1989. Exploring complexity. New York: W.H. Freeman.

Nilsson, A.E., Carlsen, H., and van der Watt, L.-M. 2015. Uncertain futures: The changing global context of the European Arctic. Report of a scenario-building workshop in Pajala, Sweden. SEI Working Paper 2015-12. Stockholm: SEI.

http://urn.kb.se/resolve?urn=urn:nbn:se:su:diva-125074

Nilsson, A.E., Bay-Larsen, I., Carlsen, H., van Oort, B., Bjørkan, M., Jylhä, K., Klyuchnikova, E., Masloboev, V., and van der Watt, L.-M. 2017a. Towards extended shared socioeconomic pathways: A combined participatory bottom-up and top-down methodology with results from the Barents region. Global Environmental Change 45:124-132. https://doi.org/10.1016/j.gloenvcha.2017.06.001

Nilsson, A.E., Bay-Larsen, I., Carlsen, H., Jylhä, K., van der Watt, L.-M., van Oort, B. 2017b. Future narratives. In: Adaptation actions for a changing Arctic. Perspectives from the Barents area. Oslo: Arctic Monitoring and Assessment Programme (AMAP). 109-126.

Nilsson, A.E., Carson, M., Cost, D.S., Forbes, B.C., Haavisto, R., Karlsdottir, A., Nymand Larsen, J., et al. 2019. Towards improved participatory scenario methodologies in the Arctic. Polar Geography. Published online 9 August 2019. https://doi.org/10.1080/1088937X.2019.1648583
O’Neill, B.C., Kriegler, E., Riahi, K., Ebi, K.L., Hallegatte, S., Carter, T.R., Mathur, R., and van Vuuren, D.P. 2014. A new scenario framework for climate change research: The concept of shared socioeconomic pathways. Climatic Change 122:387-400. https://doi.org/10.1007/s10584-013-0905-2

Petrov, A.N. 2018. Re-tracing development paths: Exploring the origins and nature of the 20th century's northern development paradigms in Russia and Canada. In: Heininen, L., and ExnerPirot, H., eds. Arctic yearbook 2018: Arctic development in theory $\&$ in practice. $1-14$.

https://arcticyearbook.com/arctic-yearbook/2018

Popiel, E. 2014. The history and future of scenarios and the U.S. Coast Guard. Washington, D.C.: The Federal Foresight Community of Interest.

https:/www.ffcoi.org/wp-content/uploads/2019/02/Historyand-Future-of-Scenarios-at-USCG_Jul-2014.pdf

President of Russian Federation. 2014. O sukhoputnykh territoriyakh Arkticheskoy zony Rossiyskoy Federatsii [On onshore territories of the Arctic Zone of the Russian Federation]. Decree of May 2, 2014. No. 296.

Prigogine, I., and Stengers, I. 1997. The end of certainty: Time, chaos, and the new laws of nature. New York: Free Press.

Rasmussen, R.O., and Jungsberg, L. 2016. How does the Foresight method work? Community involvement in the Arctic. Nordregio News 2.16:8-9.

https://nordregio.org/nordregio-magazine/issues/communityinvolvement-in-the-nordic-arctic/how-does-the-foresightmethod-work/

Razuvaev, V.V. 2016. Arktika: tri stsenariya: mezhdunarodnyye otnosheniya za Polyarnym krugom [The Arctic: three scenarios: International relations above the Arctic Circle]. Strategiya Rossii [Russia's strategy] 3:31-40.

Rotmans, J., van Asselt, M., Anastasi, C., Greeuw, S., Mellors, J., Peters, S., Rothman, D., and Rijkens, N. 2000. Visions for a sustainable Europe. Futures 32(9-10):809-831. https://doi.org/10.1016/S0016-3287(00)00033-1

Rounsevell, M.D.A., and Metzger, M.J. 2010. Developing qualitative scenario storylines for environmental change assessment. WIREs Climate Change 1(4):606-619. https://doi.org/10.1002/wcc.63

Swart, R.J., Raskin, P., and Robinson, J. 2004. The problem of the future: Sustainability science and scenario analysis. Global Environmental Change 14(2):137-146. https://doi.org/10.1016/j.gloenvcha.2003.10.002

Teh, L.S.L., Cheung, W.W.L., and Sumaila, U.R. 2017. Scenarios for investigating the future of Canada's oceans and marine fisheries under environmental and socioeconomic change. Regional Environmental Change 17(3):619-633. https://doi.org/10.1007/s10113-016-1081-5

Tsukerman, V.A., and Ivanov, S.V. 2013. Scenarios for the development and improvement of the life support systems of the Arctic zone of Russia. In: Kvithyld, A., Meskers, C, Kirchain, R., Krumdick, G., Mishra, B., Reuter, M., Wang, C., et al., eds. REWAS 2013: Enabling materials resource sustainability. Cham, Switzerland: Springer International. 404-410. 
Troll, L.E. 1970. Issues in the study of generations. Aging and Human Development 1(3):199-218. https://doi.org/10.2190/AG.1.3.c

UNDP (United Nations Development Programme). 2015. Foresight: The manual. Singapore: UNDP Global Centre for Public Service Excellence.

- 2018. Foresight manual: Empowered futures for the 2030 agenda. Singapore: UNDP Global Centre for Public Service Excellence.

USAF (United States Air Force). 2019. The future of Space 2060 and implications for U.S. strategy: Report on the Space Futures Workshop, 5 September 2019.

https://s3.amazonaws.com/images.spaceref.com/news/2019/ USAFSpace.pdf
U.S. Committee on the Marine Transportation System. 2019. A ten-year projection of maritime activity in the U.S. Arctic region, 2020-2030. Washington, D.C. 118 p.

https://pame.is/document-library/shipping-documents/arcticship-traffic-data-documents/reports/451-a-10-year-projectionof-maritime-activity-in-the-u-s-arctic-region/file

van't Klooster, S.A., and van Asselt, M.B.A. 2006. Practicing the scenario-axes technique. Futures 38(1):15-30. https://doi.org/10.1016/j.futures.2005.04.019

Wesche, S.D., and Armitage, D.R. 2014. Using qualitative scenarios to understand regional environmental change in the Canadian North. Regional Environmental Change 14(3):1095-1108. https://oi.org/10.1007/s10113-013-0537-0

Wormbs, N., ed. 2018. Competing Arctic futures: Historical and contemporary perspectives. Cham, Switzerland: Palgrave Macmillan. 